\title{
Local People's Access to Forest-Based Development Opportunities In Manokwari District
}

By Max J. Tokede, Dede Wiliam, Siân McGrath and Yosias Gandhi

\section{Introduction}

For the province of Papua, the decentralization era began in 2000, when it was granted Special Autonomy. Papua has used the opportunities provided to change its local forest management model from statutory management to a community-based system. These changes have afforded communities with customary land rights more opportunities to participate directly in managing forests as specified in Law No. 21/20011 regarding Special Autonomy for the province of Papua, and laid out in Article 67 (1) of the national Forestry Law No.41/1999.

The national framework allocates local people the rights to use, manage and control forest resources at the district level in specified areas, whether customary areas or state-owned forest estates. These rights are

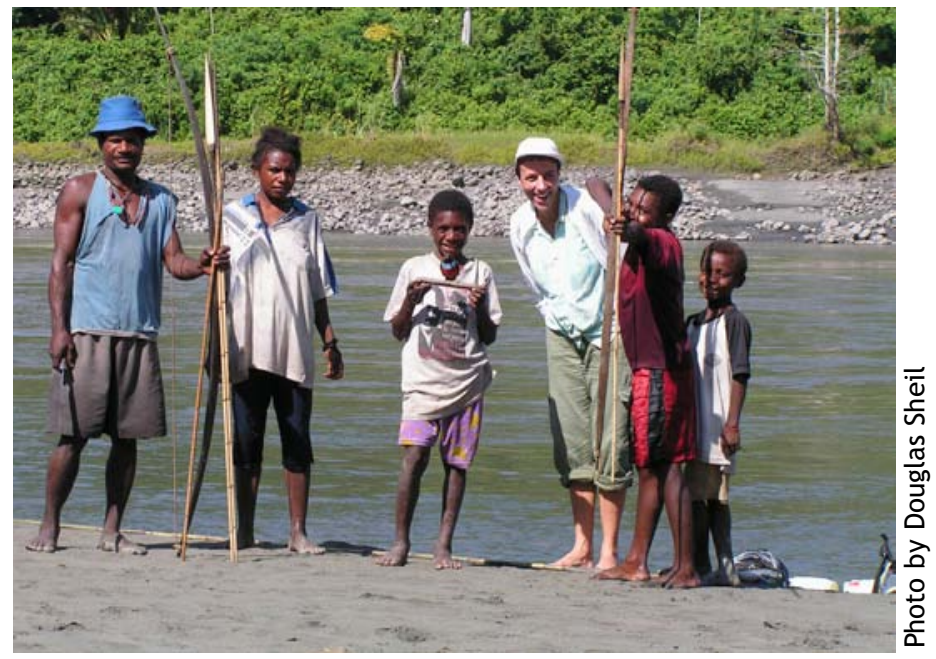
granted to formally recognised customary communities, community cooperatives, and/or private companies. Under decentralization, the Ministry of Forestry has followed the national framework for decentralization by issuing two decrees regarding harvesting rights for local communities ${ }^{2}$. The first decree, regarding Forest Product Harvesting Permits (HPHH - now revoked ${ }^{3}$ ) provided local communities with access to forest harvesting benefits from one-year 100 ha concession permits. Most districts across Indonesia followed this first decree in their regulations on community-based harvesting.

A second, national decree regarding Forest Product Harvesting Permits for Customary (Adat) Communities (HPHH-MA) regulates non-commercial activities. It is still valid and allows communities to use forest products inside or outside state-owned forests indefinitely. Guidelines for its implementation are laid out in a Director General's Implementing Decree 4 . Under decentralization Papua has followed these national regulations on customary community harvesting rights (HPHH-MA). It is the only province to have done so.

The national regulations on customary community harvesting rights are contradictory. As a result, the provincial and district governments have followed either the Ministerial Decree or its Implementing Decree. This has given them greater flexibility in the development of their forest policies. It has also meant that Papua is the only province to have drafted legislation authorizing community-based timber-harvesting permits to be issued by the provincial government. This is because the Ministerial Decree specifies that the Bupati is authorised to issue permits, but the implementing decree gives this responsibility to the Head of the District Forestry Office, with approval from the provincial governor.

Whilst the national Ministerial Decree only refers to non-commercial harvesting activities, its implementing decree refers to commercial harvesting activities, for an unlimited period of time in areas of unspecified size. As a result the areas and timeframes allocated to customary communities under provincial permits are different to those allowed by district-issued permits in Papua. 
Table 1. Policy analysis of Permit allocation systems in Manokwari District

\begin{tabular}{|c|c|c|c|}
\hline Component & Central regulation & Provincial regulation & District regulation \\
\hline Legal reference & $\begin{array}{l}\text { Ministerial Decree No. } \\
317 / \text { kpts-II/1999 on Rights to } \\
\text { Harvest Forest Products in } \\
\text { Production Forests by } \\
\text { Customary Communities. } \\
\text { Guidelines for implementation } \\
\text { are laid out in a Director } \\
\text { General's Decree (SK Dirjen } \\
\text { PHP No.199/kpts/VI-SET/1999) }\end{array}$ & $\begin{array}{l}\text { Papua Province Governor's } \\
\text { Decree No. } \\
522.2 / 3386 / \text { SET/2002 regarding } \\
\text { the Arrangements for IPK-MA. } \\
\text { Implementation Guidelines are } \\
\text { laid out in Papua Province } \\
\text { Forestry Decree (SK Dinas } \\
\text { Kehutanan Papua) No. } \\
522.1 / 1648 / 2002\end{array}$ & $\begin{array}{l}\text { Manokwari District Head's } \\
\text { Decree (SK Bupati). } \\
\text { No.274/2004 regarding } \\
\text { Permits for Customary Forest } \\
\text { Management inside State- } \\
\text { Owned Forest (production } \\
\text { zones), IHPHA. }\end{array}$ \\
\hline $\begin{array}{l}\text { Forest } \\
\text { utilisation }\end{array}$ & $\begin{array}{l}\text { Legal Ambiguity: The } \\
\text { Ministerial Decree specifies } \\
\text { harvesting for non-commercial } \\
\text { purposes only, but the } \\
\text { implementing Decree specifies } \\
\text { harvesting for commercial use. }\end{array}$ & $\begin{array}{l}\text { Harvesting for commercial } \\
\text { purposes. }\end{array}$ & $\begin{array}{l}\text { Harvesting for commercial } \\
\text { purposes. }\end{array}$ \\
\hline Permit holders & $\begin{array}{l}\text { Customary community } \\
\text { institutions formally recognised } \\
\text { under a Bupati's Decree. }\end{array}$ & $\begin{array}{l}\text { Legally constituted Community } \\
\text { Groups, business partners, HPH } \\
\text { concessionaires or other timber } \\
\text { harvesting companies and } \\
\text { Community Cooperatives } \\
\text { (Kopermas). }\end{array}$ & $\begin{array}{l}\text { The decree stipulates that the } \\
\text { permit can only be granted to } \\
\text { Community Cooperatives } \\
\text { (Kopermas). }\end{array}$ \\
\hline Authorization & $\begin{array}{l}\text { Legal Ambiguity: The } \\
\text { Ministerial Decree specifies } \\
\text { that the Bupati is authorised to } \\
\text { issue permits, but the } \\
\text { implementing Decree specifies } \\
\text { the Head of the District } \\
\text { Forestry Office, with approval } \\
\text { from the provincial governor. }\end{array}$ & $\begin{array}{l}\text { The Provincial Forestry Office is } \\
\text { authorized to issue permits with } \\
\text { a recommendation from District } \\
\text { Forestry Office }\end{array}$ & $\begin{array}{l}\text { The Bupati is authorized to } \\
\text { issues permits based on } \\
\text { technical recommendations } \\
\text { from the District Forestry } \\
\text { Office (In practice this } \\
\text { regulation prevails, all } \\
\text { permits are issued by the } \\
\text { Bupati). }\end{array}$ \\
\hline $\begin{array}{l}\text { Guidance and } \\
\text { supervision }\end{array}$ & $\begin{array}{l}\text { Allocates responsibility for } \\
\text { monitoring/implementation to } \\
\text { District Forestry Office; but the } \\
\text { Provincial Forestry Office has } \\
\text { responsibility for permit } \\
\text { application and issuance } \\
\text { processes. No technical } \\
\text { implementation guidance. }\end{array}$ & $\begin{array}{l}\text { Allocates responsibility for } \\
\text { monitoring and implementation } \\
\text { to the District Forestry Office } \\
\text { (IPK-MA permits). Unclear } \\
\text { technical implementation } \\
\text { guidance. }\end{array}$ & $\begin{array}{l}\text { Allocates responsibility for } \\
\text { monitoring and } \\
\text { implementation to the District } \\
\text { Forestry Office. Clear } \\
\text { technical implementation } \\
\text { guidance }\end{array}$ \\
\hline Timeframe & $\begin{array}{l}\text { Legal Ambiguity: The } \\
\text { Ministerial Decree specifies no } \\
\text { timeframe (non-commercial } \\
\text { harvesting), but the } \\
\text { implementing Decree specifies } \\
\text { an indefinite period "for as } \\
\text { long as the community exists" } \\
\text { (commercial harvesting). }\end{array}$ & $\begin{array}{l}\text { Permits valid for } 1 \text { year with } \\
\text { possible extension. }\end{array}$ & Permits valid for 20 years. \\
\hline Area size & Not specified & $250-1,000$ ha & 2,000 ha \\
\hline Forest zones & $\begin{array}{l}\text { In state-owned forest } \\
\text { (production and conversion } \\
\text { zones) with or without HPH } \\
\text { concessions }\end{array}$ & $\begin{array}{l}\text { In state-owned forest estate } \\
\text { (Kawasan Hutan) areas zoned } \\
\text { for production - with or without } \\
\text { existing HPH concessions, and in } \\
\text { APL (areas outside the Kawasan } \\
\text { Hutan). }\end{array}$ & $\begin{array}{l}\text { In state-owned forest estate } \\
\text { (Kawasan Hutan) areas zoned } \\
\text { for production - with or } \\
\text { without existing HPH } \\
\text { concessions, and in } \\
\text { "customary forests". }\end{array}$ \\
\hline $\begin{array}{l}\text { Environmental } \\
\text { protection }\end{array}$ & Log one plant one & Log one plant two. & $\begin{array}{l}\text { Technical Guidance: based on } \\
\text { detailed forest inventories. } \\
\text { Selective cutting with } \\
\text { (re)planting (TPTI); or clear } \\
\text { fell with artificial } \\
\text { regeneration } \\
\text { (THPB). Both options must } \\
\text { include conservation } \\
\text { management plans. }\end{array}$ \\
\hline Taxation & DR and PSDH & DR and PSDH & $\begin{array}{l}\text { Specifies: "forestry taxations" } \\
\text { are due. }\end{array}$ \\
\hline
\end{tabular}


In Manokwari, our case study district, customary communities who want access to forest resources have three options under changes introduced in the decentralization era. They can seek financial compensation from HPH concession holders; or they can apply for two different types of permit, one issued by the district government and the other by the provincial government. In line with national legislation, provincial permits can legally be allocated to individuals, private companies in partnership with customary communities, customary community organisations (LMHA) or community cooperatives. However, in practice, permits have only been issued to communities that have formally established themselves as economic community cooperatives

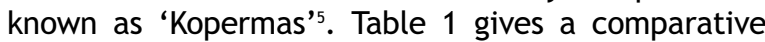
analysis of the provisions for environmental management; and community access to forest decision-making and benefits under the following policies:

1. Following Special Autonomy for Papua, the central government continued to issue large-scale $\mathrm{HPH}$ permits in Papua. Existing HPH concessions have also continued to operate. The provincial government has used its new powers to introduce a policy ${ }^{6}$ obliging HPH concessionaires to give compensation for timber exploitation to communities with customary land rights (Hak Ulayat).

2. Since 2002, local communities have accessed resources by applying for a Timber Logging Permit for Customary Communities (IPK-MA, Ijin Pemungutan Kayu Masyarakat Adat), issued by the provincial government ${ }^{7}$. These permits cover an area of $250-1,000$ ha. They are valid for one year.

3. From April 2004, a new, district government-issued Permit to Manage Customary forests (IHPHA, Ijin Hak Pengelolaan Hutan Adat) has been available, covering an area of 2,000 ha, valid for twenty years. The first permits have yet to been issued under this new district policy ${ }^{8}$.
The new, district policy now stipulates that only Kopermas are eligible for IHPHA permits. It also spells out investors' roles and obligations for long-term capacity building (training, developing logging plans with communities); infrastructure development; and it gives guidelines on profit-sharing mechanisms. Investors must be based in Manokwari, and have run a continuous business there for at least three years. People can participate in decision-making because permits must be approved by village heads or subdistrict heads, and are granted only to Kopermas. To ensure that there is enough suitable land available for local communities to benefit from the new permit system, the new district policy also obliges HPH concessionaires to make a maximum of 10,000 ha of their concessions available for customary communities seeking IHPHA permits 9 .

Our comparative analysis of the provisions laid out in national, provincial and district level regulations on customary community permit systems suggests that the district government has a strong commitment to improving local communities' livelihoods; encouraging more sustainable forest management and conservation; and better local natural resources from predatory investment companies.

\section{The Shifting Paradigm in Papua's Forest Management}

During the New Order regime, the central government's HPH policy required Community Development for Forest Villages $\left(\mathrm{PMDH}^{10}\right)$ programs. In practice, in Papua - as with other districts across Indonesia - local communities received very few benefits from forest exploitation.

Our analysis shows that decentralizing authority for forest management has significantly increased local communities' access to short-term financial benefits. It has also improved their access to decision-making,

Table 2. Comparative Access to Benefits and Decision-Making

\begin{tabular}{|c|c|c|c|c|}
\hline \multirow{2}{*}{$\begin{array}{l}\text { Category for } \\
\text { Comparison }\end{array}$} & \multirow{2}{*}{$\begin{array}{c}\text { Pre- } \\
\text { Decentralisation } \\
\text { HPH }\end{array}$} & & Decentralisation & \\
\hline & & HPH & IPK-MA & IHPHA \\
\hline Concession holders & Private companies & Private companies & Kopermas & Kopermas \\
\hline Timber Logging & HPH Concessionaires & $\begin{array}{l}\text { HPH concessionaires/ } \\
\text { (can be in partnership } \\
\text { with Kopermas) }\end{array}$ & $\begin{array}{l}\text { Investors } \\
\text { /Kopermas }\end{array}$ & Investors / Kopermas \\
\hline $\begin{array}{l}\text { Benefits for } \\
\text { Customary } \\
\text { Communities }\end{array}$ & $\begin{array}{l}\text { Community } \\
\text { empowerment } \\
\text { programs (PMDH) }\end{array}$ & $\begin{array}{l}\text { Community } \\
\text { empowerment (PMDH) } \\
\text { program, 'Entrance } \\
\text { fees' and land use } \\
\text { compensation }\end{array}$ & $\begin{array}{l}\text { Entrance Fees, } \\
\text { Profit sharing and } \\
\text { land use } \\
\text { compensation }\end{array}$ & $\begin{array}{l}\text { A wide range of } \\
\text { negotiated benefits, } \\
\text { in addition to profit } \\
\text { sharing and land use } \\
\text { compensation }\end{array}$ \\
\hline $\begin{array}{l}\text { Decision-making } \\
\text { Powers }\end{array}$ & $\begin{array}{l}\text { Central Government } \\
\text { HPH companies }\end{array}$ & $\begin{array}{l}\text { Central Government, } \\
\text { Provincial government } \\
\text { HPH companies Local } \\
\text { community 'elites' }\end{array}$ & $\begin{array}{l}\text { Provincial } \\
\text { Government, } \\
\text { customary } \\
\text { communities, } \\
\text { Kopermas and } \\
\text { investors }\end{array}$ & $\begin{array}{l}\text { District Government, } \\
\text { customary } \\
\text { communities, } \\
\text { Kopermas and } \\
\text { investors }\end{array}$ \\
\hline
\end{tabular}




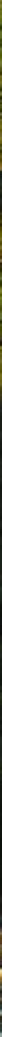

Photo by Douglas Sheil at least in relation to forestry harvesting on their own concession areas. Table 2 provides a comparison of the access to benefits and decision-making for local communities in relation to other stakeholders before and after decentralization.

Local communities' long-term development opportunities are limited because they lack the capital, expertise and technology to manage their forest resources independently. Local communities in Papua do not have the strong negotiating skills they need to deal with experienced timber companies. This is reflected by the fact that that some local communities have been grossly exploited by some forestry investors. Other communities, however, have managed to secure much more equitable agreements with investors under the Kopermas system, including commitments to developing small-scale community plantations and replanting customary forestland after logging.

The rates of various entrance fees ${ }^{11}$; proportion of profits per $\mathrm{m}^{3}$; infrastructure and planting development commitments; and other forms of land use compensation are set during negotiations between Kopermas and the commercial investor. The final deals vary radically. For example entrance fees in our case study district varied from Rp. 10 to 60 million on concessions of 1,000 ha.

There is also a large degree of variation between the ways that each Kopermas distribute benefits amongst their membership, and the levels of investment they make in long-term projects such as bridges, roads, housing, community transport and education or training.

We found that, in general, communities working in partnership with $\mathrm{HPH}$ concessionaires receive fewer benefits than those working with non-HPH commercial investors. For example, HPH concessionaires paid a maximum of Rp. 50,000 per $\mathrm{m}^{3}$ of timber harvested, whereas non-HPH investors paid up to Rp. 200,000 per $\mathrm{m}^{3}$. HPH concessionaires did make the point that they also contributed indirect benefits by investing in roads and logging ponds, which are used free of charge by Kopermas and non-HPH investors.

Over and above their cash-receipts and other benefits, individual community members have also been employed on concessions. However, as they lack commercial forestry experience, employment opportunities have been limited to guiding logging teams or working as labourers loading and unloading wood in the Timber Collection Areas (TPK). Currently communities are very dependent on investors, which can leave them in a hopeless situation when investors pull out, leaving an exhausted resource base behind them. The new district policy should improve this situation as potential investors are obliged to guarantee that community members will be involved in logging and administration, so that expertise can be transferred. They are also obliged to develop detailed plans for sustainable forest management in partnership with local communities.

\section{Conclusions}

The level of involvement in decision-making and share of benefits received by local communities varied for a number of reasons. We found cases of extreme exploitation and cases where local communities had secured relatively good deals for themselves. These cases provide some valuable lessons for the district government of Manokwari, if it is to ensure that its new policy is successfully implemented.

The small-scale concession model has generated cash payments and development investments for 
customary communities, at least in the short term. If Kopermas concessions are well managed, they can generate sufficient capital for local communities to invest in long term development initiatives, to improve their standard of living and their livelihoods options for the future.

The province will continue to issue Kopermas permits in Manokwari alongside the new, district permits system. The provincial government assesses applications and grants permits, but the district government then has responsibility for overseeing implementation, and for monitoring and enforcing regulations. Separating the process of assessing and allocating permits from the process of monitoring and enforcing their implementation limits accountability, and fails to provide communities with adequate support. For example, communities can end up negotiating the whole process with a commercial investor or $\mathrm{HPH}$ concessionaire without any contact with the provincial government.

The Provincial government should ensure that there is a written agreement between Kopermas and commercial investors, and only issue a permit once they have checked and validated this agreement. In practice, communities have not always been able to hold commercial investors to their original commitments. We found that some communities had signed an "agreement" but did not know where the investor had taken it. It was not always clear if agreements had been validated by the Provincial Forestry Office; nor was it possible to establish if a copy was held by the district Cooperatives Office (Dinas Koperasi), district Forestry Office (Dinas Kehutanan) or the provincial forestry office. This administrative confusion limits the abilities of local communities to hold investors accountable.

We found that another factor that limited equity and accountability was local communities' low level of knowledge and understanding about the Kopermas permit system. As a result, communities are not always aware of their rights or the investors' obligations. Neither the provincial policy nor the new district policy contain any sanctions for violating agreements between Kopermas and investors; or for failing to comply with regulations designed to protect the environment and ensure regeneration.

\section{Recomendations}

Local communities can now choose to apply for a 20 year district or a One-year provincial permit. Given the stronger provisions for community benefits under the district permit policy; it is likely that the majority of communities seeking new permits will opt for a district permit.

In the meantime, we recommend the following reforms:

- Develop and strengthen coordination between district communities/government agencies and the provincial government. Checks and balances could include giving the district forestry office an official role in approving provincial permit applications.

- Revise permit registration processes. Agreements could be validated by the district and the provincial forestry office. All parties to the agreement could receive a final, validated copy. Copies could be kept by both the district and the provincial agencies.

- Both the district and the provincial government could work together to reform their policies to include sanctions. They should establish a clear division of roles and responsibilities for enforcing sanctions.

- Government could support communities by giving them information about existing policies, and establish a participatory process for adapting policies in the future.

- Revenues generated from forestry activities could be re-invested in providing training, and lessonlearning opportunities. Some examples suggested by local stakeholders included:

- "exchange visits" so communities can learn from each others' experiences, stakeholders also recommended that video documentaries should be produced and widely disseminated across Papua to demonstrate different experiences and share lessons.

- Establish district forestry 'Development Forums' where all stakeholders can regularly meet and make decisions together. District members could also meet periodically in a Provincial Development Forum.

- Appropriate silviculture systems should be developed in partnership with local communities, taking into account communities' capacities, resourcedependencies, and cultural values. This will help guarantee sustainable production and forest conservation.

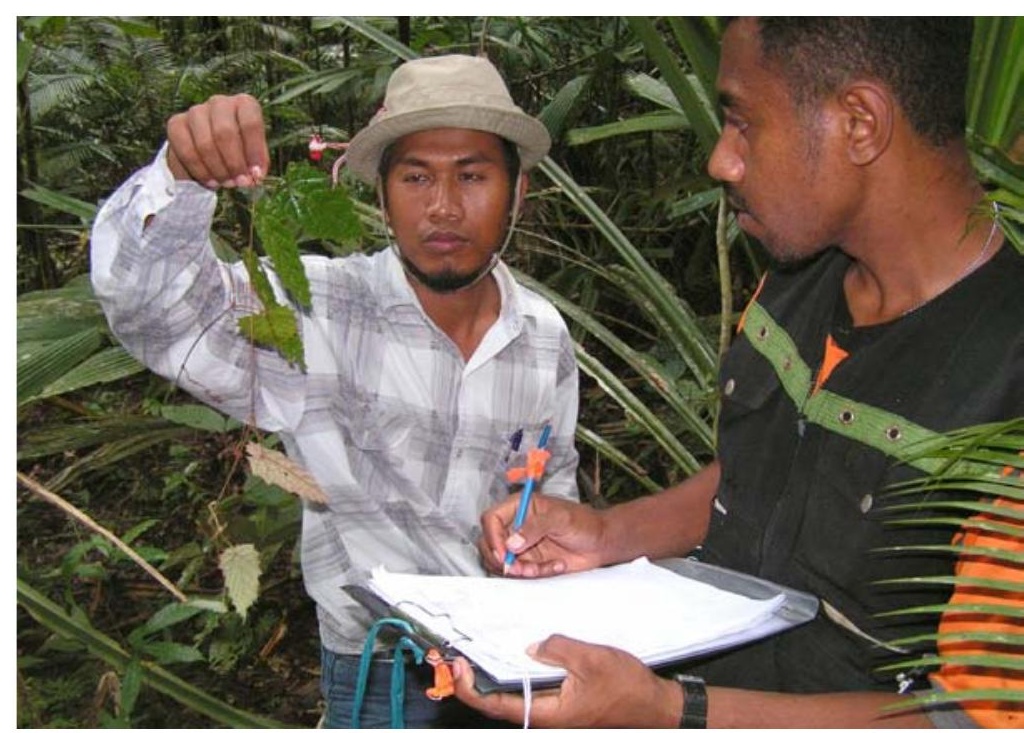

Photo by Douglas Sheil 


\section{Endnotes}

${ }^{1}$ Law No. 21/2001 Chapter XI Article 43.

${ }^{2}$ No. $310 / \mathrm{kpts}-\mathrm{Il} / 1999$ regarding the Rights to Harvest Forest Products from Production Forests (HPHH) and No. 317/Kpts-II/1999 regarding the Rights of Customary Communities to Harvest Forest Products from Production Forests (HPHH-MA).

${ }^{3} \mathrm{HPHH}$ system was cancelled by a Ministerial Decree (SK Mentri) No. 6886/kpts-II/2002 regarding Guidelines for granting IPHH Permits in Production Forests.

${ }^{4}$ Director General of Forest Utilization's Implementing Decree No. 199/Kpts/VI-Set/1999.

${ }^{5}$ The Kopermas system is organised based on a Joint decree of the Ministry of Forestry and Plantations and Ministry of Cooperative, Small-scale and Medium Enterprises No. 234/kpts-IV/1999 and 01/skb/M/ IV/1999, regarding The Empowerment of Cooperatives in the Forestry and Plantation Sector and a Ministry of Cooperative, Small-scale and Medium
Enterprises's Decree No. 107/bh/KDK/238/XI/2000 regarding the Legalisation of Community Cooperatives (Kopermas).

${ }^{6}$ SK Gubernur No. 50/2001 regarding The Standards for Giving Compensation to Customary Communities for Timber Taken from 'Ulayat' Areas.

7 SK Gubernur No. 522.2/3386/SET/2002, regarding the Arrangements for the Rights of Customary Communities to Harvest Forest Products.

8 SK Bupati No. 274/2004 regarding Permits for Customary Forest Management inside Production Forests (IHPHA).

9 SK Bupati Manokwari No. 274/2004. Chapter VI, Article 14.

10 Allocation of funds for PMDH, according to the Decree of the Minister of Forestry and Plantations No. $610 / \mathrm{Kpts}-\mathrm{II} / 1993$ is $1,000 \mathrm{Rp} / \mathrm{m}^{3}$

Max J. Tokede and Yosias Gandhi of Papua University; and Dede Wiliam and Siân McGrath of CIFOR prepared this Decentralisation Brief drawn from the report The Impacts of Special Autonomy for Papua: Empowering Local Communities through Forest-Based Development Opportunities - a case study of Manokwari District. This work has been funded by ACIAR and DFID under the project: Can Decentralisation Work for Forests and the Poor? The opinions expressed herein are those of the authors and do not necessarily reflect the views of funding agency.

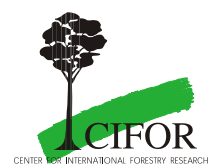

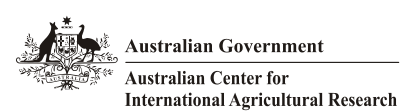

Center for International Forestry Research, CIFOR Office: Jalan CIFOR, Situ Gede, Sindang Barang, Bogor Barat 16680, Indonesia. Mailing: P.O. Box. 6596 JKPWB, Jakarta 10065, Indonesia

\section{$\mathrm{DFID}=$}

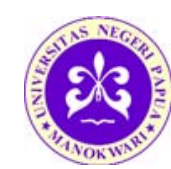

Tel: +62(251) 622622 Fax: +62(251) 622100

E-mail: cifor@cgiar.org Website: www.cifor.cgiar.org

Front page photos by: R. Pinraid and C. Cossalter

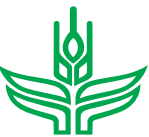

F U T U R E

HARY/EST 
30.., 